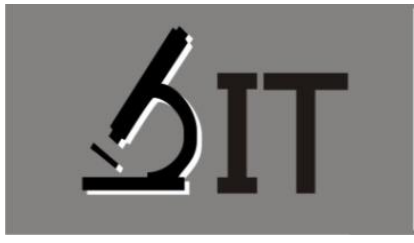

p-ISSN : $2597-8977$

e-ISSN : 2597-8985

Andi Arwan*)

Universitas Negeri Makassar

Muh. Tawil

Universitas Negeri Makassar

Ramlawati

Universitas Negeri Makassar
JIT 5 (1) (2021) 19-27

JURNAL IPA TERPADU

http://ojs.unm.ac.id/index.php/ipaterpadu

\section{PENGARUH MODEL PEMBELAJARAN INKUIRI TERBIMBING TERHADAP KETERAMPILAN BERPIKIR KRITIS PESERTA DIDIK KELAS VII SEKOLAH MENENGAH PERTAMA}

*) Correspondence Author: Andiarwano82@Gmail.com
Abstrak: Penelitian ini bertujuan untuk menganalisis: peningkatan keterampilan berpikir kritis peserta didik kelas VII SMP Negeri 2 Duampanua yang diajar dengan menggunakan pembelajaran Inkuiri terbimbing, Peningkatan keterampilan berpikir kritis peserta didik kelas VII SMP Negeri 2 Duampanua yang diajar dengan menggunakan pembelajaran konvensional. Penelitian ini merupakan penelitian eksperimen semu (Quasi-Eksperiment) dengan desain penelitian Nonequivalent Control Group Design. Populasi penelitian ini adalah seluruh peserta didik kelas VII SMPN 2 Duampanua. Pengambilan sampel melalui teknik accidental sampling sehingga diperoleh kelas VII 1 sebanyak 26 siwa sebagai kelas eksperimen dan kelas VII 4 berjumlah 25 siswa sebagai kelas kontrol. Peningkatan keterampilan berpikir kritis peserta didik kelas VII SMP Negeri 2 Duampanua dengan menggunakan pembelajaran Inkuiri terbimbing tergolong dalam kategori sedang dengan skor $\mathrm{N}$-Gain sebesar 0,65 . Peningkatan keterampilan berpikir kritis peserta didik kelas VII SMP Negeri 2 Duampanua dengan menggunakan pembelajaran konvensional tergolong dalam kategori sedang dengan skor N-Gain sebesar 0,54. Keterampilan berpikir kritis peserta didik pada kelas VII SMP Negeri 2 Duampanua yang diajar menggunakan pembelajaran Inkuiri terbimbing lebih tinggi dibanding yang diajar menggunakan pembelajaran konvensional. Hasil analisis inferensial dengan menggunakan uji-t diperoleh diperoleh hasil analisis thitung $=18,41>$ ttabel $=1,67$.

Kata kunci: Inkuiri Terbimbing, Keterampilan berpikir kritis

Abstract: This study aims to analyze the improvement of students' critical thinking skills who were taught using guided inquiry learning, and using conventional learning. This research is a quasi-experimental research (Quasi-Experiment) with Nonequivalent Control Group Design. The population of this study were all seventh grade students of SMPN 2 Duampanua. Sampling was done through accidental sampling technique so that there were 26 students in class VII 1 as the experimental class and class VII 4 as the control class. The improvement of critical thinking skills of seventh grade students of SMP Negeri 2 Duampanua by using guided inquiry learning is in the medium category with $\mathrm{N}$-Gain score of 0.65 . The improvement of critical thinking skills of seventh grade students of SMP Negeri 2 Duampanua by using conventional learning is in the medium category with $\mathrm{N}$-Gain score of 0.54 . The critical thinking skills of students in class VII SMP Negeri 2 Duampanua who were taught using guided inquiry learning are higher than those who taught using conventional learning. The results of the inferential analysis using the t-test obtained the results of the analysis tcount $=18.41>$ ttable $=1.67$

Keywords: Guided Inquiry, Critical thinking skills 


\section{PENDAHULUAN}

Pendidikan adalah usaha sadar dan terencana untuk mewujudkan suasana belajar dan proses pembelajaran agar peserta didik secara aktif mengembangkan potensi dirinya untuk memiliki kekuatan spiritual keagamaan, pengendalian diri, kepribadian, kecerdasan, akhlak mulia, serta keterampilan yang diperlukan dirinya,masyarakat, bangsa dan negara. Proses belajar mengajar meliputi seluruh aktivitas yang menyangkut pemberian materi pelajaran agar peserta didik memperoleh kecakapan dan pengetahuan bermanfaat.

Berdasarkan Kurikulum 2013, pembelajaran pada satuan pendidikan diselenggarakan secara interaktif, inspiratif, menyenangkan, menantang, memotivasi peserta didik untuk berpartisipasi aktif, serta memberikan ruang yang cukup bagi kreativitas, kemandirian sesuai bakat, minat dan pengembangan fisik serta psikologis peserta didik. Kurikulum tersebut terdapat perubahan pola pikir, yaitu pembelajaran berpusat kepada pendidik diubah menjadi pembelajaran berpusat pada peserta didik (Permendikbud, 2013). Proses pembelajaran terdiri atas lima pengalaman belajar pokok yaitu mengamati, menanya, mengumpulkan informasi, mengasosiasi, mengkomunikasikan yang diimplementasikan dalam kegiatan belajar (Permendikbud, 2013).

Unsur pendidikan yang sangat berperan penting dalam proses perkembangan pendidikan yaitu pendidik. Pendidik merupakan dasar penentu kualitas lulusan peserta didik yang baik maupun buruk. Maka dari itu sangat diperlukan kualitas pendidik yang profesional dalam proses perkembangan pendidikan. Pendidik dituntut tidak hanya pintar dalam penguasaan materi pelajaran, tetapi juga diharapkan mampu mengelola kelas dengan baik supaya proses pembelajaran berjalan dengan aktif, inovatif, kreatif,efektif, dan menyenangkan (Dewi, Nyoman, \& Wayan, 2013).

Berdasarkan pengamatan langsung proses pembelajaran IPA yang dilakukan di SMPN 2 Duampanua, peserta didik mengalami kesulitan dalam menangkap isi pesan yang disampaikan oleh pendidik selama berlangsungnya pembelajaran. Karena pada proses pembelajaran pendidik cenderung menggunakan strategi dan pembelajaran konvensional tidak sesuai dengan karakteristik materi yang diajarkan. Serta peserta didik masih kurang aktif dikelas tanpa melatih kemampuan yang dimiliki peserta didik. Proses pembelajaran IPA yang dilakukan di SMPN 2 Duampanua, peserta didik mengalami kesulitan dalam menangkap isi pesan yang disampaikan oleh pendidik selama berlangsungnya pembelajaran.

Menurut (Sutama, 2014) pembelajaran inkuiri terbimbing lebih efektif dalam meningkatkan keterampilan berpikir kritis dan kinerja ilmiah adalah model pembelajaran inkuiri. Model pembelajaran inkuiri merupakan salah satu model pembelajaran yang tidak hanya memberdayakan sains sebagai produk tetapi juga mampu memberdayakan sains sebagai proses terutama demi peningkatan kemampuan berpikir kritis serta kinerja ilmiah Menurut (simbolon, 2015) beberapa keunggulan dalam membelajarkan model inkuiri terbimbing peserta didik mengetahui konsep-konsep dasar dan ide-ide yang lebih baik, membantu mengingat pada proses belajar yang baru, memotivasi peserta didik untuk berpikir dan bekerja atas inisiatif sendiri, mendorong peserta disik untuk berpikir intuitif dan merumuskan hipotesisnya sendiri.

Peserta didik akan memperoleh pengalaman lebih bermakna dan apa yang pelajari akan lebih kuat melekat dalam pikiran mereka. Kuatnya informasi yang melekat pada memori peserta didik, tentu akan berdampak pula terhadap perolehan keterampilan berpikir kritis peserta didik (Neka, 2015). Berpikir kritis adalah proses disiplin yang secara intelektual aktif dan terampil mengkonseptulisasikan, menerapkan, menganalisis, mensintesis dan atau mengevaluasi informasi yang dikumpulkan dari atau dihasilkan oleh pengamatan, pengalaman, refleksi, penalaran, atau komunikasi, sebagai panduan untuk kepercayaan dan tindakan.terdapat beberapa indikator dari berpikir kritis adalah memberikan penjelasan sederhana, membangun keterampilan dasar, membuat inferensi,membuat penjelasan lebih lanjut dan mengatur strategi dan tekhnik (Tawil \& Liliasari, 2013). 
Beberapa hasil penelitian yang relevan dengan penelitian ini adalah penelitian yang dilakukan oleh (Sutama, 2014) yang menunjukkan nilai keterampilan berpikir kritis yang lebih tinggi pada pembelajaran menggunakan model pembelajaran inkuiri. Selain itu, (Mulyani, Wayan, \& Nyoman, 2015) melakukan penelitian komparasi peningkatan keterampilan berpikir kritis dan kinerja ilmiah peserta didik yang dibelajarkan dengan model project based learning dan model pembelajaran inkuiri terbimbing terdapat peningkatan berpikiri kritis peserta didik. (Rahmah, Lesmanawati, \& Wahidin, 2015) melakukan penelitian model pembelajaran inkuiri terbimbing untuk meningkatkan keterampilan berpikir kritis peserta didik pada pokok bahasan ekosistem kelas x di SMA Negeri 1 Krangkeng respon peserta didik terhadap penerapan model pembelajaran inkuiri terbimbing pada pokok bahasan ekosistem sebagian besar berada dalam kategori sangat kuat. Peserta didik memberikan respon yang baik terhadap penerapan model pembelajaran inkuiri terbimbing. Dengan adanya penelitian tersebut maka peneliti mencoba membuktikan hasil penelitian yang dilakukan sebelumnya dan peneliti tertarik akan penelitian tersebut agar di uji di sampel berbeda. Berdasarkan uraian diatas, maka penulis bermaksud untuk meneliti pengaruh model pembelajaran inkuiri terbimbing terhadap keterampilan berpikir kritis IPA peserta didikdikelas VII SMP Negeri 2 Duampanua.

\section{METODE}

Penelitian ini merupakan penelitian eksperimen semu (Quasy Experimental).Desain penelitian yang digunakan dalam penelitian ini adalah Pretest-Posttest Non-Equevalent Control Group Design. Eksperimen semu (Non-Equevalent Control Group Design) melibatkan dua kelas, yaitu kelas eksperimen dan kelas kontrol. Satu kelas menerapkan pembelajaran inkuiri terbimbing sebagai kelas eksperimen dan kelas yang satu menerapkan pembelajaran konvensional sebagai kelas kontrol.Penelitian ini dilaksanakan di SMPN 2 Duampanua pada semester ganjil tahun ajaran 2019/2020 (Sugiyono, 2016).

Populasi dalam penelitian ini adalah seluruh peserta didik kelas VII SMPN 2 Duampanua yang terdiri dari 5 kelas dengan jumlah 130 peserta didik.Teknik pengambilan sampel yang dilakukan adalah Porposive Sampling.Dari 10 kelas, dipilih 2 kelas yang memiliki skor rata-rata hasil belajar kedua kelas yang hampir sama. Kelas yang terpilih adalah kelas VII.1 sebagai kelas ekperimen dan kelas VII.4 sebagai kelas kontrol.

Teknik pengumpulan data diperoleh dengan menggunakan instrumen tes keterampilan berpikir kritis. Tes keterampilan berpikir kritis berupa soal pilihan ganda yang terdiri dari 20 item soal yang telah dibuat berdasarkan indikator keterampilan berpikir kritis. Soal pretest dan posttest yang diberikan masing-masing sama untuk kelas kontrol dan kelas eksperimen. Jika benar diberi skor 1 dan jika salah diberi skor 0 . Validasi soal sudah dilakukan oleh tim validator dimana kelayakan soalnya sudah bisa digunakan dengan mengikuti isrtument keterampilan berpikir kritis.

\section{HASIL DAN PEMBAHASAN}

\section{Hasil}

\section{a. Analisis Deskriptif}

Hasil analisis deskriptif menunjukkan deskripsi nilai keterampilan berpikir kritis peserta didik yang diajar dengan mengunakan model inkuiri terbimbing dan model pembelajaran konvensional SMPN 2 Duampanua tahun ajaran 2019/2020 semester ganjil. 


\section{1.) Analisis N-gain}

Pengumpulan data hasil penelitian dilakukan menggunakan alat pengumpulan data berupa tes pilihan ganda. Untuk mengetahui hasil penelitian yang dilakukan, maka perlu diadakan perbandingan hasil pretest dengan posttest dari kedua kelompok, serta membandingkan normal gain dari kedua kelompok tersebut.

Setelah diperoleh skor pretest dan posttest dari kedua kelas penelitian, dilakukan analisis $\mathrm{N}$ Gain untuk mengetahui peningkatan hasil belajar IPA peserta didik. Hasil analisis N-Gain seperti pada Tabel 1 berikut.

Tabel 1. Rata-Rata N- Gain Tes Keterampilan Berpikir Kritis

\begin{tabular}{lcc}
\hline \multicolumn{1}{c}{ Kelas } & Rata-Rata Skor N-Gain & Kategori \\
\hline $\begin{array}{l}\text { Kelas Eksperimen } \\
\text { Kelas Kontrol }\end{array}$ & 0,644 & Sedang \\
\hline
\end{tabular}

Berdasarkan tabel 1 menunjukkan peningkatan keterampilan berpikir kritis peserta didik yang diajar di kelas eksperimen dan kelas kontrol dapat diketahui melalui analisis N-gain. Berdasarkan data yang telah diperoleh rerata $\mathrm{N}$-Gain pada kelas eksperimen adalah 0,644 berada pada kategori sedang dan pada kelas kontrol 0,549 juga pada kategori sedang.

\section{2.) Analisis N-gain setiap indikator berpikir kritis}

Hasil analisis skor $\mathrm{N}$-gain setiap indikator berpikir kritis peserta didik melalui data pretes dan posttest pada kelas eksperimen dan kelas kontrol dapat pada Tabel 2.

Tabel 2. Skor N-gain Setiap Indikator Berpikir Kritis.

\begin{tabular}{|c|c|c|c|c|}
\hline \multirow{2}{*}{ Indikator } & \multicolumn{2}{|c|}{ Kelas Eksperimen } & \multicolumn{2}{|c|}{ Kelas Kontrol } \\
\hline & Skor & Kriteria & Skor & Kriteria \\
\hline Memberikan penjelasan sederhana & 0,56 & Sedang & 0,47 & Sedang \\
\hline Membuat inferensi & 0,69 & Sedang & 0,57 & Sedang \\
\hline Membuat penjelasan lebih lanjut & 0,64 & Sedang & 0,53 & Sedang \\
\hline Mengatur strategi dan teknik & 0,72 & Tinggi & 0,42 & Sedang \\
\hline
\end{tabular}

Berdasarkan tabel 2 menunjukkan bahwa pada kelas eksperimen terdapat tiga indikator keterampilan berpikir kritis yaitu memberikan penjelasan sederhana 0,56 , membuat inferensi 0,69 dan membuat penjelasan lebih lanjut 0,64 berada pada kategori sedang. Satu indikator keterampilan berpikir kritis berada pada kategori tinggi yaitu indikator mengatur strategi dan teknik dengan skor $\mathrm{N}$-gain 0,72.

Pada kelas kontrol juga terdapat empat indikator keterampilan berpikir kritis pada kategori sedang yaitu memberikan penjelasan sederhana dengan skor $\mathrm{N}$-gain 0,47 , membuat inferensi 0,57 , mengatur strategi dan teknik 0,53 dan indikator membuat penjelasan lebih lanjut dengan skor N-gain 0,42. 


\section{b. Analisis Statistik Inferensial}

Hasil analisis statistik inferensial disajikan untuk pengujian hipotesis, dalam uji-t dengan taraf signifikansi $a=0,05$. Syarat yang harus dipenuhi untuk pengujian hipotesis adalah data yang diperoleh harus terdistribusi normal dan mempunyai variansi yang homogen. Oleh karena itu terlebih dahulu dilakukan uji normalitas dan uji homogenitas.

\section{1.) Uji prasyarat}

a) Uji normalitas

Uji normalitas dilakukan untuk mengetahui apakah distribusi sebaran data normal atau tidak. Uji normalitas dilakukan dengan menggunakan chi kuadrat $\left(\mathrm{x}^{2}\right)$ dengan taraf signifikan $\alpha=$ 0,05 . Masing-masing hasil perhitungan chi kuadrat hitung dari kelas eksperimen dan kelas kontrol kemudian dibandingkan chi kuadrat tabel sehingga dari hasil perbandingan tersebut dapat diketahui apakah data terdistribusi normal atau tidak. Apabila hasil chi kuadrat hitung lebih kecil dari chi kuadrat tabel maka data dinyatakan terdistribusi normal.

Hasil perhitungan tabel diperoleh nilai $X^{2}$ hitung sebesar 9,0393932 sedangkan nilai $X^{2}$ tabel pada taraf signifikan $a=0,05$ dan derajat kebebasan $(\mathrm{dk})=\mathrm{n}-1$ diperoleh $X^{2}$ tabel $=11.07050$. Berdasarkan hasil analisis data tersebut dinyatakan bahwa $X^{2}{ }_{\text {hitung }}<X^{2}$ tabel yaitu 9,0393932<11.07050, maka data pada kelas eksperimen (pretest) terdistribusi normal. Hasil

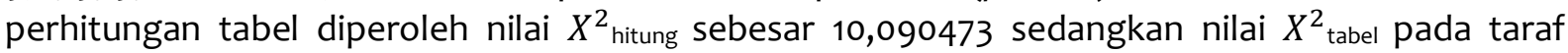
signifikan $a=0,05$ dan derajat kebebasan $(\mathrm{dk})=\mathrm{n}-1$ diperoleh $X^{2}$ tabel $=11.07050$. Berdasarkan hasil analisis data tersebut dinyatakan bahwa $X^{2}$ hitung $<X^{2}$ tabel yaitu 10,090473<11.07050 maka dapat disimpulkan data pada kelas eksperimen (posttest) terdistribusi normal dengan jumlah sampel peserta didik 26 orang.

Hasil perhitungan tabel diperoleh nilai $X^{2}$ hitung sebesar 1,373406 sedangkan nilai $X^{2}$ tabel pada taraf signifikan $a=0,05$ dan derajat kebebasan $(\mathrm{dk})=\mathrm{n}-1$ diperoleh $X^{2}$ tabel $=11.07050$. Berdasarkan hasil analisis data tersebut dinyatakan bahwa $X^{2}{ }_{\text {hitung }}<X^{2}$ tabel yaitu 1,373406<11.07050 maka dapat disimpulkan data pada kelas kontrol (pretest) terdistribusi normal. Hasil perhitungan tabel diperoleh nilai $X^{2}$ hitung sebesar 5,91006 sedangkan nilai $X^{2}$ tabel pada taraf signifikan $a=0,05$ dan derajat kebebasan $(\mathrm{dk})=\mathrm{n}-1$ diperoleh $X_{\text {tabel }}^{2}=11.07050$. Berdasarkan hasil analisis data tersebut dinyatakan bahwa $X^{2}$ hitung $<X^{2}$ tabel yaitu 5,91006<11.07050 maka dapat disimpulkan data pada kelas kontrol (posttest) terdistribusi normal dengan jumlah sampel peserta didik 25 orang.

Tabel 3. Pengujian Normalitas Data

\begin{tabular}{cccc}
\hline Data & Eksperimen & Kontrol & Keputusan \\
\hline $\mathrm{n}$ & 26 & 25 & Data berdistibusi normal \\
$x^{2}$ hitung pretest & 9,0393932 & 1,373406 & Data berdistibusi normal \\
$x^{2}$ hitung postet & 10,090473 & 5,91006 & Data berdistibusi normal \\
$x^{2}$ tabel & 11.07050 & 11.07050 & Data berdistibusi normal \\
\hline
\end{tabular}

b) Uji homogenitas

Setelah kedua sampel dinyatakan terdistribusi normal, maka dilakukan uji homogenitas menggunakan data N-gain. Tujuan dari dilakukannya uji homogenitas untuk mengetahui apakah 
data dalam penelitian ini memiliki varians yang sama (homogen) atau tidak (heterogen). Berdasarkan hasil analisis pengujian homogenitas varians dengan menggunakan uji-F.

Pengujian homogenitas dilakukan dengan menguji data posttest pada kelas eksperimen dan kelas kontrol. Berdasarkan hasil perhitungan untuk data dari kelas eksperimen dan kontrol diperoleh hasil perhitungan diperoleh nilai $F_{\text {hitung }}$ sebesar 0,235874166 sedangkan nilai $F_{\text {tabel }}$ pada taraf signifikan $a=0,05$ dan derajat kebebasan $(\mathrm{dk})=\mathrm{n}-1$ diperoleh $\mathrm{F}_{\text {tabel }}=1.9749594$ dengan jumlah sampel peserta didik 26 orang untuk kelas eksperimen dan jumlah sampel peserta didik 25 orang untuk kelas eksperimen .Berdasarkan hasil analisis data tersebut dinyatakan bahwa $F_{\text {hitung }}$ $<F_{\text {tabel }}$ yaitu 0,235874166 <1.9749594, maka dapat disimpulkan data bersifat homogen.

Pengujian homogenitas data pretest pada kelas eksperimen dan kelas kontrol diperoleh

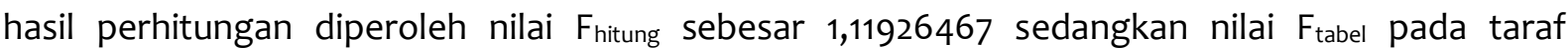
signifikan $\alpha=0,05$ dan derajat kebebasan $(\mathrm{dk})=\mathrm{n}-1$ diperoleh $\mathrm{F}_{\text {tabel }}=1.9749594$. Berdasarkan hasil analisis data tersebut dinyatakan bahwa $F_{\text {hitung }}<F_{\text {tabel }}$ yaitu 1,11926467<1.9749594, maka dapat disimpulkan data bersifat homogen.

\section{3) Uji hipotesis}

Berdasarkan uji prasyarat analisis, menunjukkan bahwa data dalam penelitian ini terdistribusi normal dan homogen sehingga pengujian hipotesis dapat dilaksanakan. Pengujian hipotesis dilakukan untuk mengetahui jawaban hipotesis yang diajukan. Pengujian hipotesis uji-t

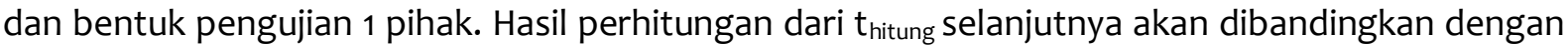
nilai $t_{\text {tabel }}$ dengan derajat kebebasan $(\mathrm{dk})=\mathrm{n}_{1}+\mathrm{n}_{2}-2$ dan taraf signifikan 0,05.

Berdasarkan pengujian hipotesis dengan menggunakan uji-t.hasil analisis $t_{\text {hitung }}=18,41>t_{\text {tabel }}$ = 1,67 . Hal ini berarti $H_{0}$ ditolak dan $H_{1}$ diterima. Sehingga dapat disimpulkan bahwa Terdapat pengaruh model pembelajaran inkuiri terbimbing terhadap keterampilan berpikir kritis jika dibandingkan dengan model pembelajaran konvensional pada peserta didik kelas VII SMP Negeri 2 Duampanua.

\section{Pembahasan}

Penelitian yang telah dilakukan dimaksudkan untuk mengetahui peningkatan keterampilan berpikir kritis peserta didik yang dibelajarkan dengan menggunakan model inkuiri terbimbing dan yang dibelajarkan dengan menggunakan model pembelajaran konvensional pada SMP Negeri 2 Duampanua.

Hasil analisis $\mathrm{N}$-gain ditemukan bahwa keterampilan berpikir kritis peserta didik pada kelas eksperimen diperoleh kategori sedang diperoleh skor rata-rata 0.653 dan pada kelas kontrol diperoleh skor rata-rata 0.549 termasuk kategori sedang. Dengan menggunakan model inkuiri terbimbing membuat peserta didik bekerja dalam tim dan semua peserta didik harus menguasai pelajaran tersebut, sehingga peserta didik dituntut aktif. Apabila peserta didik menguasai pelajaran, maka keterampilan berpikir kritis juga akan meningkat. Kelas eksperimen yang diajar menggunakan inkuiri terbimbing lebih tinggi keterampilan berpikir kritis dibandingkan kelas kontrol yang tidak diajar menggunakan model pembelajaran inkuiri terbimbing. Menurut (Sutama, 2014), Pembelajaran inkuiri terbimbing lebih efektif dalam meningkatkan keterampilan berpikir kritis dan kinerja ilmiah. Model pembelajaran inkuiri merupakan salah satu model pembelajaran yang tidak hanya memberdayakan sains sebagai produk tetapi juga mampu memberdayakan sains sebagai proses terutama demi peningkatan kemampuan berpikir kritis serta kinerja ilmiah. Model pembelajaran inkuiri adalah suatu rangkaian kegiatan yang melibatkan kegiatan belajar secara maksimal seluruh kemampuan peserta didik untuk mencari dan menyelidiki secara sistematis, kritis, logis, analitis, sehingga mereka dapat merumuskan sendiri penemuannya dengan penuh percaya diri. Hal ini disebabkan karena kerjasama antar peserta didik 
terjalin dengan lancar, pendidik maupun peserta didik sudah bisa menjalankan fungsi dan perannya dalam metode pembelajaran inkuiri.

Menurut (Mulyani, Wayan, \& Nyoman, 2015) model pembelajaran inkuiri terbimbing melibatkan siswa untuk berpikir secara aktif dan menemukan pengertian yang ingin diketahuinya. Dalam model pembelajaran ini siswa dilibatkan dalam proses penemuan melalui pengumpulan data dan tes hipotesis. Pengetahuan dan keterampilan yang diperoleh siswa bukan dari hasil mengingat fakta-fakta, tetapi hasil dari penemuan sendiri. Keterlibatan siswa secara maksimal dalam proses kegiatan belajar adalah kegiatan mental intelektual dan sosial emosional, sehingga kegiatan dapat terarah secara logis dan sistematis. Adanya penelitian sebelumnya maka dengan mudah membantu kita membuktikan hasil penelitian dan kita juga dapat membandingkan dengan penelitian sebelumnya.

Pada kelas eksperimen peserta didik terlibat aktif dalam proses pembelajaran, terutama dalam mengerjakan LKPD peserta didik terlihat tertarik mengerjakannya. Selama proses berlangsung peserta didik memahami sendiri konsep materi pelajaran pada LKPD. LKPD dalam model pembelajaran inkuiri terbimbing (guided inquiry) dikelas mampu menarik perhatian peserta didik. Selain itu LKPD yang berisikan wacana tersebut dapat memberikan informasi kepada peserta didik dalam kegiatan belajar sehingga dengan mudah memahami.

Pada kelas eksperimen peserta didik terlibat aktif dalam proses pembelajaran, terutama dalam melakukan eksperimen peserta didik mencari tahu sendiri tetapi tetap dibimbing dalam mengerjakannya.Pada kelas eksperimen juga peserta didik lebih mudah memahami pembelajaran dan lebih kritis dalam melakukan eksperimen dimana peserta didik memahami akar permasalahan sehingga keterampilan berpikir kritis peserta didik lebih tinggi. Sama dengan proses pembelajaran pada kelas kontrol, peserta didik juga diberikan perlakuan dalam mengerjakan eksperimen akan tetapi hanya pendidik yang menjadi sumber pembelajaran. Dimana pendidik hanya berperan sebagai pengarah dalam membangun potensi peserta didik sedangkan peserta didik sebagai pusat pembelajaran. Hasil penelitian yang diperoleh didukung oleh penelitian yang dilakukan (Sutama, 2014) yang menyatakan menggunakan strategi pembelajaran inkuiri dengan materi pembelajaran biologi yang bersifat autentik dan realistik untuk meningkatkan kemampuan berpikir kritis dan kinerja ilmiah siswa. Strategi pembelajaran inkuiri sudah terbukti dapat meningkatkan kinerja ilmiah dan menumbuh kembangkan kemampuan berpikir kritis siswa sehingga baik untuk diterapkan dalam pembelajaran.

Memperkuat bukti bahwa model pembelajaran Inkuiri Terbimbing lebih berpengaruh terhadap keterampilan berpikir kritis jika dibandingkan dengan pembelajaran konvensional. Maka dilakukan uji statistik inferensial yang berupa uji hipotesis. Uji hipotesis ini dilakukan untuk mengetahui kebenaran hipotesis yang telah diajukan. pengujian hipotesis dapat dilakukan dengan menggunakan uji-t. Hasil analisis inferensial dengan menggunakan uji-t. Hasil analisis data diperoleh bahwa nilai $t_{\text {hitung }}$ lebih besar dari $t_{\text {tabel }}$ yang artinya hipotesis $\mathrm{H}_{\mathrm{o}}$ ditolak dan hipotesis $\mathrm{H}_{1}$ diterima. Oleh karena itu, dapat disimpulkan bahwa keterampilan berpikir kritis yang dibelajarkan dengan model inkuiri terbimbing lebih tinggi dari pada keterampilan berpikir kritis yang dibelajarkan menggunakan model pembelajaran konvensional.

\section{KESIMPULAN}

Berdasarkan hasil penelitian maka dapat disimpulkan bahwa: Keterampilan berpikir kritis peserta didik kelas VII SMP Negeri 2 Duampanua yang diajar mengunakan model pembelajaran inkuiri terbimbing diperoleh skor rata-rata 0.653 tergolong kategori sedang, Keterampilan berpikir kritis peserta didik kelas VII SMP Negeri 2 Duampanua yang diajar mengunakan model pembelajaran konvensional diperoleh skor rata-rata 0.549 tergolong kategori sedang dan, Keterampilan berpikir kritis peserta didik yang diajarkan dengan model pembelajaran inkuiri 
terbimbing lebih tinggi dari pada keterampilan berpikir kritis peserta didik yang dibelajarkan dengan model pembelajaran konvensional berdasarkan hasil analisis inferensial dengan menggunakan uji-t diperoleh diperoleh hasil analisis thitung $=18,41>$ ttabel $=1,67{ }^{\prime}$ ' ' ' ini berarti Ho ditolak dan H1 diterima. Sehingga dapat disimpulkan bahwa Terdapat $\mathrm{p} \epsilon$ u uh Model pembelajaran inkuiri terbimbing terhadap keterampilan berpikir kritis jika dibandingkan dengan model pembelajaran konvensional pada peserta didik kelas VII SMP Negeri 2 Duampanua.

\section{DAFTAR PUSTAKA}

Dewi, N. I., Nyoman, D. I., \& Wayan, S. (2013). Pengaruh Model Pembelajaran Inkuiri Terbimbing Terhadap Sikap IImiah Dan Hasil Belajar Ipa . E-Journal Program Pasca Sarjana Universitas Pendidikan Ganesa Jurusan Pendidikan Dasar .

Mulyani, N. K., Wayan, K., \& Nyoman, S. (2015). Komparasi Peningkatan Keterampilan Berpikir Kritis Dan Kinerja Ilmiah Peserta didik Yang Dibelajarkan Dengan Model Projec Based Learning Dan Inkuiri Terbimbing . E-Jjournal Pasca Sarjana Universitas Pendidikan Ganesa.

Neka. (2015). Pengaruh Model Pembelajaran Inkuiri Terbimbing Berbasis Lingkungan Terhadap Keterampilan Berpikir Kritis Dan Penguasaan Konsep Ipa Kelas V Sd Gugus Viii Kecamatan Abang. E-journal Pasjasarjana Univeristas Ganesha.

Permendikbud, No.68.2013. Kerangka Dasar Dan Struktur Kurikulum Sekolah Menengah Pertama/Madrasah Tsanawiyah. Jakarta: Menteri Pendidikan.

Rahmah, A., Lesmanawati, I. R., \& Wahidin. (2015). Penerapan Model Pembelajaran Inkuri Terbimbing Untuk Meningkatkan Keterampilan Berpikir Kritis Peserta didik Pada Pokok Bahasan Ekosistem Kelas X Di Sma Negeri 1 Krangkeng. Journal Scientie Educatiaon.

Simbolon, D. H. (2015). Penagruh Model Pembelajaran Inkuiri Terbimbing Berbasis Eksperimen Riil Dan Laboratorium Virtual Terhadap Hasil Belajar Fisika Peserta didik . Jurnal Pendidikan dan Kebudayaan .

Sugiyono. (2016). Metode Penetian Kuantitatif, Kualitatif, Dan R\& D. Bandung: Alfabeta.

Sutama, N. (2014). Pengaruh Model Pembelajaran Inkuiri Terhadap Keterampilan Berpikir Kritis dan Kinerja Ilmiah Pada Pelajaran Biologi Kelas Ix Ipa Sma Negeri 2 Amlapura. Jurnal Program Pasca Sarjana Universitas Pendidikan Ganesa .

Tawil, M., \& Liliasari. (2013). Berpikir Kompleks Dan Implementasinya Dalam Pembelajaran Ipa. Makassar: Badan Penerbit UNM. 


\section{Arwan}

Mahasiswa Program Studi Pendidikan IPA FMIPA UNM, aktif melakukan penelitian pada bidang Pendidikan IPA, dapat dihubungi melalui email: andiarwano82@Gmail.com

\section{Muh. Tawil}

Dosen Program Studi Pendidikan IPA FMIPA UNM, aktif melakukan penelitian pada bidang Pendidikan IPA, dapat dihubungi melalui email: muh.tawil@unm.ac.id

\section{Ramlawati}

Dosen Program Studi Pendidikan IPA FMIPA UNM, aktif melakukan penelitian pada bidang Pendidikan IPA, dapat dihubungi melalui email: ramlawati@unm.ac.id 